\title{
Correlation between maternal thyroid stimulating hormone and birth weight of neonate
}

\section{Nishita Shettian, Hema Venkata Naga Sai Sudha Pavuluri*}

Department of Obstetrics and Gynaecology, AJ Institute of Medical Sciences and Research Center, Mangalore, Karnataka, India

Received: 04 December 2021

Accepted: 27 December 2021

\section{*Correspondence:}

Dr. Hema Venkata Naga Sai Sudha Pavuluri,

E-mail: pavulurisudha755@gmail.com

Copyright: (c) the author(s), publisher and licensee Medip Academy. This is an open-access article distributed under the terms of the Creative Commons Attribution Non-Commercial License, which permits unrestricted non-commercial use, distribution, and reproduction in any medium, provided the original work is properly cited.

\section{ABSTRACT}

Background: The aim of this study is to determine the pregnancy outcomes in women with thyroid disorders.

Methods: This is a retrospective observational study conducted in the department of obstetrics and gynaecology of AJ institute of medical sciences and research centre from the month of March to September 2021. The first trimester thyroid stimulating hormone (TSH) level and birth weight of new born is collected from hospital records, study participants included all the pregnant mothers who were admitted and delivered in the labour ward of AJ institute of medical sciences Results: According to our study low birth weight in neonates in euthyroid, hypothyroid, hyperthyroid participants were $21.4 \%, 61.5 \%$, and $100 \%$ respectively.

Conclusions: This study indicates that there is an association between maternal thyroid levels and neonatal birth weight. A higher TSH concentration during first trimester of pregnancy is associated with low birth weight. Based on these findings, it is recommended that maternal thyroid levels be monitored closely in the first trimester and initiate timely treatment in case of altered thyroid levels during pregnancy in order to have a healthy pregnancy and healthy baby with no compromise in the fetal weight.

Keywords: First trimester TSH levels, Low-birth weight, SGA, Preterm, Sub clinical hypothyroidism, Hyperthyroidism

\section{INTRODUCTION}

Pregnancy has a profound impact on the thyroid gland and thyroid function. The gland increases $10 \%$ in size during pregnancy in iodine-replete countries and by $20-40 \%$ in areas of iodine deficiency. To meet the challenge of increased metabolic needs during pregnancy, the thyroid adapts through changes in thyroid hormone economy and in the regulation of the hypothalamic-pituitary-thyroid axis. $^{1}$

Consequently, thyroid function test results of healthy pregnant women differ from those of healthy non pregnant women. This calls for pregnancy-specific and ideally trimester specific reference intervals for all thyroid function tests. ${ }^{1}$
If trimester-specific reference ranges for $\mathrm{TSH}$ are not available in the laboratory, the following reference ranges are recommended: First trimester: 0.1-2.5 mIU/L, second trimester: $0.2-3.0 \mathrm{mIU} / \mathrm{L}$ and third trimester: $0.3-3.0$ $\mathrm{mIU} / \mathrm{L}$.

Overt hypothyroidism is increase in serum TSH $(>10$ $\mathrm{mU} / \mathrm{L})$ as a result of decreased thyroxine and negative feedback while subclinical hypothyroidism is serum TSH levels in the range of 4-10 mU/L with normal range of thyroxine level. ${ }^{2}$

In pregnancy thyrotropic activity of hCG results in a decrease in serum TSH in the first trimester. Therefore, during pregnancy, women have lower serum TSH concentrations than before pregnancy. 
The adverse neonatal outcomes include preterm birth, low birth weight, increased admission to neonatal intensive care and an increase in perinatal morbidity and mortality. 3,4

In view of potential adverse outcomes associated with maternal thyroid dysfunction and obvious benefits of treatment it is recommended to do routine screening for thyroid dysfunction.

Low Birth Weight includes women who have undergone full-term deliveries with birth weight less than 2.5 kilograms. ${ }^{5}$

The main aim of this study is to determine if there is association between first trimester TSH and birth weight.

\section{METHODS}

This is a retrospective observational study conducted in the department of obstetrics and gynaecology of AJ institute of medical sciences and research centre, Kuntikana, Mangalore from the month of September to March 2021.

First trimester TSH levels and birth weight of newborn of all the eligible study participants were taken from hospital records, maintained in the medical records department of the institute. The eligible criteria are mentioned below.

\section{Inclusion criteria}

All pregnant women between 19 to 40 years, patients who delivered between 37 to 42 weeks of gestation and pregnancy with live fetus were included in the study.

\section{Exclusion criteria}

Patients with previous history of thyroid disorders, multiple gestation, preterm, pregnant women with autoimmune disorders and patients with any other medical comorbidities were excluded from the study.

\section{Statistical analysis}

The data collected was entered in Microsoft excel version 2017 and analysed using trail version of SPSS-23 (Statistical package for the social sciences).

For summarizing continuous variables, measures of central tendency and dispersion were used. For summarizing categorical variables, frequencies and percentages were used. Appropriate graphs were used for ease of representation. Tests of significance were used as per the requirement of objectives.

To determine the association between thyroid function status and categories of birth weight, chi-square test of significance was used. To determine the association between thyroid function status and birth weight (when birth weight is considered as a continuous variable), oneway ANOVA test was used.
As TSH is an important parameter of the thyroid function tests, its correlation with birth weight was assessed separately using Pearson's correlation test and was represented graphically using scatter plot. A $\mathrm{p} \geq 0.05$ was considered as significant.

\section{RESULTS}

In our study total 200 participants, aged between 18-40 years were included and their association with birth weight of baby is noted. According to the available data it is noted that there is no association between the age of mother and birth weight of newborn (Table 1).

According to collected data, most of them delivered at 38 weeks of gestation (i.e., 70 participants, 35\%) (Table 2). Total 101 participants delivered vaginally and remaining through cesarean section (Table 3).

TSH level in first trimester of study participants was collected, in which 173 have normal range of TSH level where as 26 having hypothyroidism and 1 have hyperthyroidism (Table 4). Birth weight of newborn is noted and categorized into low birth weight if weight is $<2.5 \mathrm{~kg}$, total 54 newborns belong to low birth weight according to our study (Table 5).

According to our study low birth weight is more seen in mothers with altered thyroid status, accounting $61.5 \%$ in hypothyroid, $100 \%$ in hyperthyroid patients.

Figure 1 shows a significant correlation between maternal thyroid levels and birth weight of newborn.

Table 1: Association between mothers' age group and baby's birth weight.

\begin{tabular}{|c|c|c|c|}
\hline \multirow{2}{*}{$\begin{array}{l}\text { Age } \\
\text { group } \\
\text { (Years) }\end{array}$} & \multicolumn{3}{|c|}{$\begin{array}{l}\text { Birth weight categories [Frequency (Row } \\
\text { percentages)] }(\%)\end{array}$} \\
\hline & $\begin{array}{l}\text { Low birth } \\
\text { weight }\end{array}$ & $\begin{array}{l}\text { Normal birth } \\
\text { weight }\end{array}$ & $\begin{array}{l}\text { High birth } \\
\text { weight }\end{array}$ \\
\hline $18-20$ & $1(14.3)$ & $6(85.7)$ & 0 \\
\hline $21-25$ & $14(31.1)$ & $31(68.9)$ & 0 \\
\hline $26-30$ & $9(27.3)$ & $23(69.7)$ & $1(3)$ \\
\hline 31-35 & $22(31)$ & 49 (69) & 0 \\
\hline $36-40$ & $8(18.2)$ & $36(81.8)$ & 0 \\
\hline
\end{tabular}

Chi square statistic $=8.379 ; \mathrm{df}=8 ; \mathrm{p}=0.39$.

Table 2: Distribution of study participants as per their period of gestation (POG) at the time of delivery, $(\mathbf{n}=\mathbf{2 0 0})$.

\begin{tabular}{|lll|}
\hline $\begin{array}{l}\text { POG at } \\
\text { delivery (Weeks) }\end{array}$ & Frequency & $\begin{array}{l}\text { Percentage } \\
(\%)\end{array}$ \\
\hline 37 & 53 & 26 \\
\hline 38 & 70 & 35 \\
\hline 39 & 65 & 32 \\
\hline 40 & 12 & 6 \\
\hline
\end{tabular}


Table 3: Mode of delivery of study participants, $(n=200)$.

\begin{tabular}{|lll|}
\hline Mode of delivery & Frequency & $\begin{array}{l}\text { Percentage } \\
(\%)\end{array}$ \\
\hline Vaginal & 101 & 50.5 \\
\hline Caesarean section & 99 & 49.5 \\
\hline
\end{tabular}

Table 4: Distribution of study participants as per their thyroid's status in first trimester of pregnancy, $(n=200)$.

\begin{tabular}{|lll|}
$\begin{array}{l}\text { Thyroid status in } \mathbf{1}^{\text {st }} \\
\text { trimester }\end{array}$ & Frequency & $\begin{array}{l}\text { Percentage } \\
(\%)\end{array}$ \\
\hline Euthyroidism & 173 & 86.5 \\
\hline Hypothyroidism & 26 & 13 \\
\hline Hyperthyroidism & 1 & 0.5 \\
\hline
\end{tabular}

Table 5: Birth weight categories of the newborns.

\begin{tabular}{|lll|}
\hline $\begin{array}{l}\text { Birth weight } \\
\text { categories }(\mathbf{K g})\end{array}$ & Frequency & $\begin{array}{l}\text { Percentage } \\
(\%)\end{array}$ \\
\hline Normal $(\mathbf{2 . 5 - 4 )}$ & 145 & 72.5 \\
\hline Low $(<\mathbf{2 . 5})$ & 54 & 27 \\
\hline High $(>\mathbf{4})$ & 1 & 0.5 \\
\hline
\end{tabular}

Table 6: Association between mothers' thyroid status during $1^{\text {st }}$ trimester of pregnancy and baby's birth weight.

\begin{tabular}{|c|c|c|c|}
\hline \multirow{2}{*}{$\begin{array}{l}\text { Thyroid status in } \\
1^{\text {st }} \text { trimester }\end{array}$} & \multicolumn{3}{|c|}{$\begin{array}{l}\text { Birth weight categories } \\
\text { [Frequency (Row \%)] }\end{array}$} \\
\hline & $\begin{array}{l}\text { Low } \\
\text { birth } \\
\text { weight }\end{array}$ & $\begin{array}{l}\text { Normal } \\
\text { birth } \\
\text { weight }\end{array}$ & $\begin{array}{l}\text { High } \\
\text { birth } \\
\text { weight }\end{array}$ \\
\hline Euthyroidism & $37(21.4)$ & $135(78)$ & $1(0.6)$ \\
\hline Hypothyroidism & $16(61.5)$ & $10(38.5)$ & 0 \\
\hline Hyperthyroidism & $1(100)$ & 0 & 0 \\
\hline
\end{tabular}

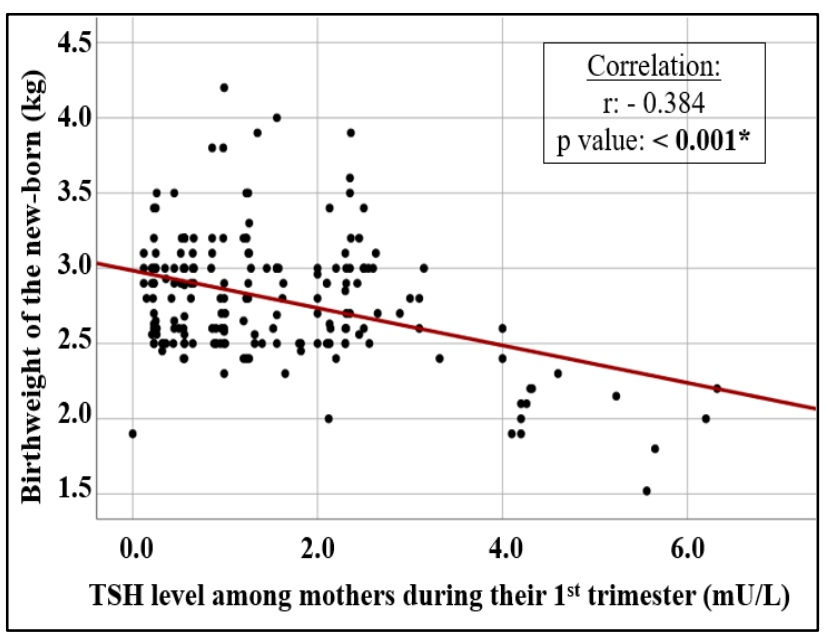

Figure 1: Correlation between mothers' thyroid status during $1^{\text {st }}$ trimester of pregnancy and baby's birth weight.

\section{DISCUSSION}

The thyroid levels of the mother have shown a great impact on the fetal growth and development. ${ }^{6}$ The fetus is completely dependent on maternal thyroid levels for its growth and development during the initial stages of pregnancy.

According to many studies there is association between the maternal thyroid levels and pregnancy outcome. ${ }^{7}$

This was a retrospective observational study done in AJ institute of medical sciences mainly to observe the correlation between maternal thyroid levels and birth weight of the newborn.

In our study the age group between 18-40 years were included and there was no association between the age of participants and birth weight of newborn.

In our study total number of euthyroid, hypothyroid, hyperthyroid participants are $86.5 \%, 13 \%, 0.5 \%$ respectively.

Based on Danish nationwide registers, there is increase in diagnosis of thyroid dysfunction during first trimester from 1995 onwards.

Children born to mothers with a diagnosis of thyroid dysfunction before, during or after pregnancy had increased risk of preterm birth, deviation from average birth weight and length and birth weight not appropriate for gestational age. ${ }^{8}$

Thyroid hormone regulates different metabolic and anabolic processes in both mother and fetus throughout gestation. It controls fetal growth by facilitating placentation and regulation of metabolism, fetal glucose and oxygen consumption as well as other co-factors directly affecting skeletal growth, tissue differentiation and accretion. ${ }^{9}$

The low-birth-weight babies in euthyroid, hypothyroid, hyperthyroid participates were found to be $21.4 \%, 61.5 \%$, $100 \%$ respectively showing statistical significance with altered thyroid status in our study. The obtained results are similar to the meta-analysis conducted by Derakhshan where maternal hypothyroidism is associated with SGA and low birth weight. ${ }^{10}$

\section{Limitations}

In this study only birth weight is correlated with maternal TSH level and sample size is less.

\section{CONCLUSION}

This study indicates that there is an association between maternal thyroid levels and neonatal birth weight. A higher TSH concentration during first trimester of pregnancy is 
associated with low birth weight. Based on these findings, it is recommended that maternal thyroid levels be monitored closely in the first trimester and initiate timely treatment in case of altered thyroid levels during pregnancy in order to have a healthy pregnancy and healthy baby with no compromise in the fetal weight.

Funding: No funding sources

Conflict of interest: None declared

Ethical approval: Not required

\section{REFERENCES}

1. Alexander EK, Pearce EN, Brent GA, Brown RS, Chen H, Dosiou C et al. 2017 guidelines of the American thyroid association for the diagnosis and management of thyroid disease during pregnancy and the postpartum. Thyroid. 2017;27(3):315-89.

2. Wiles KS, Jarvis S, Nelson-Piercy C. Are we overtreating subclinical hypothyroidism in pregnancy? BMJ. 2015;351:h4726.

3. Casey BM, Dashe JS, Wells E. Subclinical hypothyroidism and pregnancy outcomes. Obstet Gynecol. 2005;105(2):239-45.

4. Kiran Z, Sheikh A, Islam N. Maternal characteristics and outcomes affected by hypothyroidism during pregnancy. BMC pregnancy and childbirth. 2019;19:476.
5. World Health Organization. International statistical classification of diseases and related health problems, tenth revision, world health organization, Switzerland. 1992.

6. De Escobar GM, Obregon MJ, Del Rey FE. Role of thyroid hormone during early brain development. Eur J Endocrinol. 2004;151:U25-37.

7. Krassas GE, Poppe K, Glinoer D: Thyroid function and human reproductive health. En docr Rev. 2010;31:702-55

8. Andersen SL, Olsen J, Wu CS, Laurberg P. Low Birth Weight in Children Born to Mothers with Hyperthyroidism and High Birth Weight in Hypothyroidism, whereas Preterm Birth Is Common in Both Conditions: A Danish National Hospital Register Study. Eur Thyroid J. 2013;2:135-44.

9. Barjaktarovic M, Korevaar TI, Chaker L, Jaddoe VW, De Rijke YB, Visser TJ et al. The association of maternal thyroid function with placental hemodynamics. Hum Reprod. 2017;32(3):653-61.

10. Derakhshan A, Peeters RP, Taylor PN, Bliddal S, Carty DM, Meems $\mathrm{M}$ et al. Association of maternal thyroid function with birth weight: a systematic review and individual-participant data meta-analysis. Lancet Diabetes Endocrinol. 2020;8(6):501-10.

Cite this article as: Shettian N, Pavuluri HVNSS Correlation between maternal thyroid stimulating hormone and birth weight of neonate. Int J Reprod Contracept Obstet Gynecol 2022;11:55-8. 